\title{
Pain Relief
}

National Cancer Institute

\section{Source}

National Cancer Institute. Pain Relief. NCI Thesaurus. Code C112216.

A lessening of pain following an intervention. 